\title{
The Influence of Role Conflict and Role Overload to Job Satisfaction
}

\author{
Rutinaias Haholongan*, Dedi Kusdinar \\ Department of management \\ Sekolah Tinggi Ilmu Ekonomi Indonesia \\ Jakarta, Indonesia \\ *rutinaias@stei.ac.id
}

\begin{abstract}
Human resources are considered as an important source of development for the company, for the best use of human resources is not neglected to provide knowledge, skills and abilities that are controlled by employees with roles assigned to the organization. This study aims to explain whether the variable role conflict, role overload on job satisfaction. The sample used in this study was 130 respondents. This test is carried out using multiple linear regression analysis. Role conflict, role overload on job satisfaction has an effect of $47.2 \%$. The implication of this research is that the company is expected to be able to reduce the excess workload by giving empathy, motivation, bonuses to employees, so that heavy work becomes lighter and job satisfaction is achieved.
\end{abstract}

\section{Keywords: role conflict, role overload, job satisfaction}

\section{INTRODUCTION}

Awareness in maximizing and maintaining the quality of each mechanism in each line of the company, it is necessary to have good management in a company, one important part that must be managed, namely human resources. Therefore, the skills and competencies of human resources in each company will determine the results to be obtained by the company. The effectiveness of a working condition is determined by how far the working conditions are in accordance with the resources and the environment. In order to achieve these goals, resources are always required to be able to increase work productivity for the sake of continuing improvement in job satisfaction as well as company income and profits. If in a company with many employees who experience productivity and health problems, the company can be disrupted. The disruption in question includes several things, among them there is no employee passion that causes work productivity to decline, this results in a routine that results in boredom and role conflict, role overload

The existence of role conflict and role overload is something that is quite influential, not only for employees themselves in relation to work pressure, job satisfaction but also for the organization where they work which affects the quality of work that is not in line with expectations

Working conditions serve as a means to direct or regulate good activities so that leaders or managers can work calmly, comfortably, so that productivity will be controlled in accordance with what is desired by the organization or company. Employees who experience role conflict will feel that their work is a burden that must be done. Circumstances underlie a compulsion in work, so the work done does not provide maximum results, in accordance with the expectations and goals of the company. Role Overload is a situation where the amount of work obtained by a person exceeds the limits of his ability to complete the work if by himself [1]

The general objective is to determine the effect between role conflict and role overload on job satisfaction.

The research questions are as follows:

- Research Question 1 (RQ1): What is the effect of role conflict on job satisfaction?

- Research Question 2 (RQ2): What is the effect of role overload on job satisfaction?

This study is guided by the following hypothesis:

- Hypothesis 1 (H1): There is an influence between role conflict on job satisfaction

- Hypothesis $2(\mathrm{H} 2)$ : There is an influence between role overload on job satisfaction.

\section{A. Job Satisfaction}

Job satisfaction is a pleasant or unpleasant emotional state of employees in looking at their work [2]. Job satisfaction is the result of employees' perceptions of how well their work provides what is considered important [3]. The factors that affect job satisfaction can be used job descriptive index (JDI) there are five namely [4]:

- Payments such as salaries and wages

- Work it self

- Job promotion

- Supervision (Supervision)

- Co-workers

There are five factors that can influence the emergence of job satisfaction, which are as follows. 
- Person-role conflict includes the employee's interpretation of role expectations that conflict with values, codes of conduct or not in accordance with their abilities.

\section{Role Overload}

Role overload is a situation in which the amount of work obtained by a person exceeds the limits of his ability to complete the work if by himself. Role overload is a conflict of priorities arising from the hope that someone can carry out a broad task that is impossible to do in a limited time.

Impact of role overload:

- Damaging and detrimental to achieving one's goals.

- Causing a low level of job satisfaction and a desire to keep working in the company / intuition.

Role overload indicator:

- Work under time pressure (have a tight deadline)

- Work under pressure.

- Complete tasks that are too difficult.

- Doing things that are not important.

- Supervisory attitude that is inconsistent.

\section{METHODS}

Collecting data using a questionnaire is a data collection technique obtained by providing well-structured question items. With the questionnaire, the data obtained can be used to support this research. This questionnaire was made with a Likert scale with the following weights: Strongly Agree $=5$; Agree $=4 ;$ Disagree $=3 ;$ Disagree $=2 ;$ Strongly Disagree $=1$ [6].

The sample size can be determined by the number of questions in the questionnaire multiplied by five (5). So the determination of the number of samples in this study the calculation is 26 questions x $5=130$ respondents. Analytic methods describe analytic methods used to solve research problems, where the data obtained will be processed using SPSS software (Product Statistics and Service Solutions). The analysis begins with testing the validity and reliability of the questionnaire and multiple linear regression testing conducted with SPSS software. 22.00

- Descriptive Statistics Measurement to describe the characteristics of the research sample by percentage, to answer research questions and arrange dimensions in descending order.

- Multiple regression analysis to test the validity of the study form, the impact of independent variables and their dimensions on the dependent variable and size.

- One-sample Kolmogorov-Smirnov to ensure that data follows normal distribution [7].

The stages of this study were divided into 3 stages, namely 
The role conflict variable shows a significance value of

- Determine the research problem, at this stage the researcher conducts a preliminary study.

- Data collection, at this stage the researcher began by determining the source of the data, namely books relating to the problem. At this stage it ends with collecting data using observation and documentation methods.

- Analysis and presentation of data, namely analyzing data and finally drawing conclusions.

\section{RESULTS AND DISCUSSION}

Distribution of questionnaires as a whole 130 sheets or $100 \%$. Questionnaires collected were 130 sheets or $100 \%$, questionnaires were not collected $0 \%$ and questionnaires that could be processed were 130 or $100 \%$.

The reliability coefficient is calculated, according to Cronbach Alpha for completely internal consistency and for each variable. The results were as shown in Table 1:

TABLE I. THE VALUE OF RELIABILITY COEFFICIENT

\begin{tabular}{|l|l|l|}
\hline \multicolumn{3}{|c|}{ Reliability Statistics } \\
\hline \multicolumn{1}{|c|}{ Variable } & Cronbach's Alpha & \multicolumn{1}{c|}{ N of Item } \\
\hline Role Conflict & 0,775 & 4 \\
\hline Role Overload & 0,904 & 5 \\
\hline Job Satisfaction & 0,950 & 13 \\
\hline
\end{tabular}

From the reliability test results above obtained 3 outputs from the variables obtained by each variable having a reliability value (Cronbach's Alpha) above 0.60, it can be concluded that the measuring instrument in this study is reliable.

TABLE II. The VALUE Normality ONE -SAMPLE Kolmogorov SMIRNOV TEST

\begin{tabular}{|c|c|c|}
\hline \multicolumn{2}{|c|}{ Description } & $\begin{array}{c}\text { Unstandardized } \\
\text { Residual }\end{array}$ \\
\hline $\mathrm{N}$ & & 130 \\
\hline \multirow{2}{*}{ Normal Parameters ${ }^{\mathrm{a}, \mathrm{b}}$} & Mean & 0.0000000 \\
\hline & Std. Deviation & 0.35494261 \\
\hline \multirow[t]{3}{*}{ Most Extreme Differences } & Absolute & 0.051 \\
\hline & Positive & 0.048 \\
\hline & Negative & -0.051 \\
\hline Test Statistic & & 0.051 \\
\hline Asymp. Sig. (2-tailed) & & $.200^{\mathrm{c}, \mathrm{d}}$ \\
\hline
\end{tabular}

Based on table II, the calculation results using the normality test shows the sig value of KS-Z of $0.200>0.05$ so that the data is said to be normal.

TABLE III. SUMMARY OF RESULTS OF DATA

\begin{tabular}{|c|c|c|c|c|}
\hline Variable & T & Sig & F & Sig \\
\hline Role conflict & 0.627 & 0.532 & \multirow{2}{*}{58.573} & \multirow{2}{*}{0.000} \\
\hline Role Overload & 4.597 & 0.000 & & \\
\hline Adjusted $R$ square & 47.2 & & \\
\cline { 1 - 2 }
\end{tabular}
0.532 greater than 0.05 so hypothesis 1 (one) is rejected, meaning that role conflict has no effect on job satisfaction. The role overload variable shows $\beta=0.820$ and the significance value of 0.000 is smaller than 0.05 . So that hypothesis 2 two is accepted means that role overload has a positive effect on job satisfaction. Job satisfaction is influenced by role conflict (X1) and role overload (X2) simultaneously by $47.2 \%$ and the remaining $52.8 \%$ is influenced by other factors outside the study.

This study provides results that explain the role conflict has no effect on employee job satisfaction. This is evidenced by the significance value $0.532>0.05$. This is contrary to the proposed hypothesis that is influential on job satisfaction. In reality, Company still feels there is a mismatch between work roles and their expectations.

Employees experiencing mismatch expectations such as compliance with one expectation will make it difficult or impossible to effectively meet the expectations of another. Employees realize that their work is hard, but the work should jobs that cause role conflict, but employees are still able to control themselves from awareness of work responsibilities that must be considered so that employee job satisfaction is maintained. The number of jobs still makes employees feel satisfied with the facilities and infrastructure that support the the General Manager. The results showed that employees responded positively to work demands and responsibilities, not affecting satisfaction with their work.

This study reinforces the findings of which states that role conflict does not affect job satisfaction, role conflict at high or low levels does not affect employee job satisfaction [8]. which states that role conflict has an effect on job satisfaction, carrying out tasks at one boss but not in accordance with other superiors, inadequate facilities in carrying out tasks and doing tasks not in accordance with the desires will decrease job satisfaction which indicates that the role of conflict [9].

This study provides results that explain the role overload effect on employee job satisfaction. This is evidenced by the significance value of $0,000<0.05$. This is consistent with the proposed hypothesis that is influential on job satisfaction. Role overload has an influence on job satisfaction, meaning that the higher the role overload causes the lower the job satisfaction and the lower the role overload causes the higher the job satisfaction. There are various factors that cause role overload. One cause is the increase in work.

Role overload is also not only caused by physical factors, namely the increase in the amount of work but also caused by increased workload. Role overload can occur because of expectations that are too big on the role of employees, meaning that there are excessive expectations of something that can be done by employees.

Role overload affects job satisfaction. Supporting job satisfaction causes lower levels of role overload [9]. Role overload had an effect on job satisfaction. The occurrence of be done. Although employees are faced with various kinds of completion of the work, as well as support from colleagues and 


\section{REFERENCES}

role overload in the work environment affects the level of job satisfaction caused by work environment support [10].

\section{A. Managerial Implications}

In practice, when work pressures are in the form of excess workload, the Company can minimize the occurrence of these stresses by making work schedules / work priorities for employees. For conditions of role conflict, it can be overcome by using mentoring on new employees. Companies are expected to create job satisfaction by providing empathy, motivation, bonuses to employees, so that heavy work becomes lighter and job satisfaction is achieved.

\section{CONCLUSION}

In general, the results of this study reveal that there is no significant effect of conflict on job satisfaction. Different from Role overload variable influences job satisfaction. Supporting coworkers, the absence of role conflict, the work they can enjoy and cultural conditioning and a very conducive work climate based on religion, the belief to work as worship, then the desire to leave the organization if there are other opportunities will be suppressed and the negative impact of factors that can cause job dissatisfaction can be minimized.
[1] J.B. Arden, Bekerja tanpa Stress (Cara mengatasi berbagai tekanan hari kerja), vol. 1. Jakarta: PT Bhuana Ilmu Populer Kelompok Gramedia, 2008.

[2] T.H. Handoko, Manajemen Personalia dan Manahjemen Sumber Daya Manusia, edisi kedua, cetakan keenambelas. Yogyakarta: Penerbit BPFE, 2008.

[3] R. Indrawan, "Pengaruh konflik peran terhadap stres kerja dengan ketidakpastian dan kepuasan kerja sebagai variabel mediasi (Studi Pada PT. Air Mancur Karanganyar)," Universitas Sebelas Maret, 2009, Unpublished.

[4] F. Luthans, Perilaku Organisasi. Yogyakarta: PT. Andi, 2006.

[5] P. Hersey, K.H. Blanchard, and D.E. Johnson, Management of Organizational Behavior: Leading Human Resources, 9th ed. London: Pearson prentice Hall, 2008.

[6] Sugiyono, Metode Penelitian Kuantitatif, Kualitatif, dan R dan D. Bandung: Alfabeta, 2008.

[7] G. Imam, Aplikasi Analisis Multivariate Dengan Program SPSS. Semarang: Badan Penerbit Universitas Diponegoro, 2013.

[8] A. Altaf and M.A. Awan, "Moderating Affect of Workplace Spirituality on the Relationship of Job Overload and Job Satisfaction," Journal of Business Ethics, vol. 104, no. 1, pp. 93-99, 2011.

[9] Bedeian, "The Effect of Role Overload and Role conflict, Organizational Commitment and Turnover Intention on Job satisfaction," The IUP Journal of Management Research, vol. XIII, 2016.

[10] K.R. Sowmya and N. Panchanatham, "Factors influencing role overload on job satisfaction of banking sector employees in Chennai, India," Journal of Law and Conflict Resolution, vol. 3, no. 5, pp. 76-79, 2011. 